\title{
Climatic Variation: Effects on Stress Levels, Feed Intake, and Bodyweight of Broilers
}

\section{-Author(s)}

\section{Osti R'}

Bhattarai D"

Zhou D'

College of Agriculture Economics and Management, Huazhong Agricultural University, Wuhan 430070, People's Republic of China

" College of Animal Science and Technology, Huazhong Agricultural University, Wuhan 430070, People's Republic of China

\section{ABSTRACT}

Chickens tolerate a very narrow range of climatic variation, and therefore, it is essential to determine the most suitable climatic area and weather for broiler production in open-house systems. In this study, 3060 broilers were used as experimental birds to investigate the effects of seasonal differences and climatic variations on the growth performance of broilers reared in an open-house system. Birds were kept under various treatment models that differ in climate Tropic zone, sub tropic zone and temperate zones. Data were recorded during JulyAugust as summer months and January-February as winter months. Collected data was analyzed using the least square procedure given by Harvey-1990. Significantly higher $(p<0.05)$ level of corticosteroids and $\mathrm{H} / \mathrm{L}$ ratio of between the experimental birds was observed and consequent effect on feed intake was determined. The body weight and FCR at 42 day was significantly $(p \leq 0.05)$ higher during winter season in subtropical zone. Subtropical climatic zone was found significantly better than other climatic zone. Efficient management of broiler farming that corresponds for effective feed intake during heat/cold stress to maximize bird's efficiency can significantly increase production efficiency and acquiesce highest profit to broiler farming.

\section{INTRODUCTION}

Physiological stress can have deleterious effects on the overall performance and body growth of meat-type poultry (Sams, 1997; Mashaly et al., 2004), and this is still a challenging subject for poultry producers and academic. It is estimated that the worldwide demand for poultry products (meat and eggs) will rise exponentially in the coming decades. The human population is expected to increase in $33 \%$ by 2050 (UNO, 2015) and this will result in an increase of overall food production of 70\% (Ramachandran, 2014), and hence, increase the demand of poultry meat and eggs to feed this huge human population in next few decades. Broiler production is an important sector of the poultry industry, comprising $25 \%$ of overall meat production, and has increased in 125\% between 1999 and 2009 (Windhorst, 2011). Protein from chicken meat and eggs is the cheapest meat source for human consumption. However, a wide range of climatic variations greatly influences the productivity of broilers.

Broilers are challenged with infections, feedstuff variation, and climate changes, which may negatively impair the productivity of the commercial poultry industry (Shini et al., 2008). Climate change and animal production are linked, and the effects of climate change on livestock and poultry production is evident all over the world (Mengesha, 2011). Stress directly affects the physiology and welfare of poultry, and result in lower profitability (Barnett \& Hemsworth, 
2003). Although there are many types of stressors, their overall effects are often similar. Stressors activate the sympathetic adrenomedullary (SAM) and hypothalamic-pituitary-adrenal (HPA) axes, resulting in the release of catecholamines and glucocorticoids, respectively (Belda et al., 2015). Backyard farmers in developing countries rear poultry irrespective of climate and seasonal variation, and do not know its influence on overall bird performance.

A deeper knowledge of poultry management, reproduction, genetics, and nutrition is essential to meet the future demands not only to supply food to the human population, but also to provide profitability for the poultry farmers and companies, which consequently affect the global economy. Poultry production is common in subtropical zones, particularly in Asian countries, where the poultry industry is expanding (Chowdhury et al., 2014). The interaction of genetics with the environment in specific geographical locations may affect broiler growth traits (Okere, 2014). At present, climatic variation is a key threat for poultry industry, especially for marginal poultry farmers in open-house systems. Poultry of different breeds and ages react differently to climatic variations (Alade \& Ademola, 2013).

Broilers present optimal feed intake and weight gain when reared within the comfort zone (Al-Aqil et al., 2009). Poultry growth performance is not only inherited, but it is also greatly affected by the environment (Babinszky et al., 2011). Therefore, data on environmental rearing conditions and their effects on poultry production need to be generated to allow the development of common strategies to face the adverse effects of the climate change. In this study, we hypothesized that the productivity of broilers reared in different climatic zones (tropical, subtropical and temperate) would differ as a result of environmental stress level. Commercial feed formulation has evolved to supply nutrients and energy to match the bird's requirements as close as possible. In this research article, we compared total feed intake, body growth performance, water intake, mortality rates, stress hormone level (heterophil/lymphocyte ratio)of broilers birds in three different geographical areas in two different seasons (summer and winter).

\section{MATERIALS AND METHODS}

\section{Study period, studied area, data source and survey of the chicken production}

The study period was from January 2015 to December 2015, with two important periods for weather variables having the direct effect on birds' activity. The study was conducted in three different climatic zones of Nepal: southern plains (Tarai), hills, and northern mountain belts, which are characterized by tropical, subtropical, and temperate climate, respectively (Table 1 ). These areas present significant differences in altitude and average weather conditions. Nepal has altitudinal variation from $75 \mathrm{~m}$ (meter) to $8848 \mathrm{~m}$, variable land topography and climate. Environmental temperature ranges from $7^{\circ} \mathrm{C}$ (the northern belt) to $38^{\circ} \mathrm{C}$ (the southern belt). The southern part of the Nepal presents extreme heat and high humidity during the summer, whereas the northern part of Nepal, at high altitude, is characterized by severe cold and low humidity. Secondary data from government survey (MOAC, 2014) was used to choose the study area for the conduction of the research, and finally, the district with the higher broilers population in each geographic zone was chosen as the study area. The experiment was carried out in two different seasons (July-August and January-February) in each study area, which presented different temperature, rainfall and relative humidity values.

\section{Feed Formulation and Ingredients}

Feeds were based on the feed stuffs available and feed additives (Table2). Three different feeds were formulated, according to the guidelines of the Cobb500 manual, for the following rearing phases: 1) starter (0 to 10 days of age): standard mash diet, 2) grower (11 to 22 days of age): standard pelleted diet, and 3) finisher (23 days to slaughter age): standard pelleted diet.

Table 1 - Average altitude, humidity, rainfall and temperature of the studied locations

\begin{tabular}{|c|c|c|c|c|c|c|c|}
\hline \multirow[t]{2}{*}{ Experimental location } & \multirow[t]{2}{*}{ Altitude (m) } & \multicolumn{2}{|c|}{ Humidity* (\%) } & \multicolumn{2}{|c|}{ Rainfall* (mm) } & \multicolumn{2}{|c|}{ Temperature* $\left({ }^{\circ} \mathrm{C}\right)$} \\
\hline & & Summer & Winter & Summer & Winter & Summer & winter \\
\hline Tropical & Below 1000 & 90 & 62 & 125 & 32 & 37 & 22 \\
\hline Subtropical & 1000 to 2000 & 77 & 54 & 88 & 37 & 29 & 15 \\
\hline Temperate & $2000-3000$ & 55 & 36 & 31 & 11 & 14 & 5 \\
\hline
\end{tabular}

*average value 


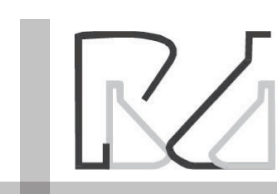

Table 2 - Feed composition (units in kg)

\begin{tabular}{lccc}
\hline Feeds ingredients & Starter & Grower & Finisher \\
\hline Corn & 500 & 480 & 500 \\
Rice pollard & 80 & 100 & 120 \\
De-fatted rice meal & 0 & 60 & 50 \\
Soybean meal & 204 & 140 & 120 \\
Mustard meal & 50 & 50 & 40 \\
Meat and bone meal & 50 & 40 & 30 \\
Sunflower meal & 32 & 22 & 30 \\
Corn gluten (30\%) & 48 & 60 & 70 \\
Limestone & 0 & 10 & 0 \\
Dicalcium phosphate & 10 & 10 & 10 \\
Molasses & 20 & 22 & 24 \\
Feed additives & \multicolumn{3}{c}{} \\
$\begin{array}{l}\text { Salt+ vitamins+ mycotoxin } \\
\text { binders+ medicines+ }\end{array}$ & 6 & 6 & 6 \\
probiotics, etc.) & 1000 & 1000 & 1000 \\
Total (kg) & $2950 \mathrm{kcal} / \mathrm{kg}$ & $3000 \mathrm{kcal} / \mathrm{kg}$ & $3100 \mathrm{kcal} / \mathrm{kg}$ \\
\hline Energy level & $21.8 \%$ & $19.5 \%$ & $18.3 \%$ \\
\hline \begin{tabular}{l} 
Protein level \\
\hline
\end{tabular}
\end{tabular}

\section{Experimental design and bird management}

Treatments consisted of summer (T1), and winter (T2), which were further divided into three different climates: tropical (plains; T1R1 and T1R2), subtropical(hills; T2R1 and T2R2), and temperate (mountains, T3R1 and T3R2) as shown in Table 3. Each treatment was replicated three times.

Table 3 - Experimental treatments

\begin{tabular}{|c|c|c|c|c|c|c|}
\hline & \multicolumn{3}{|c|}{ Summer (T1) } & \multicolumn{3}{|c|}{ Winter (T2) } \\
\hline Tropical zone & T1R1 & T1R2 & T1R3 & T2R1 & T2R2 & T2R3 \\
\hline Subtropical zone & T1R4 & T1R5 & T1R6 & T2R4 & T2R5 & T2R6 \\
\hline Temperate Zone & T1R7 & T1R8 & T1R9 & T2R7 & $\mathrm{T} 2 \mathrm{R} 8$ & T2R9 \\
\hline
\end{tabular}

A total of 3060 Cobb 500 broiler hatchlings were used, with 1020 birds per study area and reared according to the Cobb 500 management guidelines (Cobb-Vantress, 2011). Hatchlings were placed in opensided houses. In the first week, brooding temperature was maintained at $35^{\circ} \mathrm{C}$ and then gradually reduced at $2.5^{\circ} \mathrm{C}$ per week to reach $25^{\circ} \mathrm{C}$ house temperature in the $6^{\text {th }}$ week, and maintained thereafter. A mixture of sawdust with rice husks was used as litter material, after the house floor was spread with dry limestone. At placement, water was offered to chicks to avoid dehydration. Feed and water were offered ad libitum, and light was provided 24 hours per day. All birds received a standard diet with the same formulation and ingredients, manufactured in the same feed mill. The feed was offered twice daily and feed residues were daily collected and weighed in the morning and in the evening. Vaccination schedule, stocking density, and number of feeders and drinkers were according to
Climatic Variation: Effects on Stress Levels, Feed Intake, and Bodyweight of Broilers

the guidelines of Cobb 500 manual (Cobb-Vantress, 2011)

\section{Blood collection and corticosterone levels}

The stress response of the experimental birds was determined at 42 days of age. In order to minimize handling stress, each bird captured was isolated for five minutes before blood collection.

Blood was collected from the wing vein of 42 -d-old experimental birds ( $n=17$, per replicate) in $3 \mathrm{~mL}$ syringes with sodium heparin as anticoagulant, and place in duly and individually identified tubes. Blood samples were refrigerated until analysis and centrifuged at 500 $\mathrm{Xg}$ for $15 \mathrm{~min}$ at $5^{\circ} \mathrm{C}$. Heterophil to lymphocyte ratio $(\mathrm{H} / \mathrm{L})$ and blood corticosterone level were measured as indicators of stress level.

Whole blood was smeared on slides, and examined in oil immersion under a light microscope at $\times 1000$ magnification. One hundred white blood cells were counted to determine the frequencies of the various cell types and to calculate $\mathrm{H} / \mathrm{L}$ ratios.

Blood corticosterone level was measured by enzyme immunoassay using a commercial kit (OCTEIA CORT HS, Immunodiagnostic Systems Ltd., Bolton, UK). All samples were run in duplicate and using the kit calibrators at each analysis. Absorbance was measured at $450 \mathrm{~nm}$, with a reference wavelength of $650 \mathrm{~nm}$, in an ELISA microplate reader (MRX® II Dynex Technologies, USA).

\section{Data Collection}

Feed offer and residues were daily weighed and recorded to calculate precise feed intake. Water was provided in water troughs using a 2-L bucket, and next morning the remaining water was collected from the troughs and measured to determine water consumption.

At 42 days of age, all birds were weighed using an electronic top-loading balance. Individual weight gain was calculated weekly for the 6-week experimental period. The comparative study was done to find out the effect of weather and season on the average feed intake and weight gain. Finally, the feed conversion ratio (FCR) was calculated by dividing total feed intake by total weight gain.

Mortality was daily recorded, and the mortality rate calculated for the total experimental period.

\section{Statistical Analysis}

The effects of treatments on growth parameters were analyzed by the least square analysis of the 
data with unequal subclass numbers (Harvey, 1990). One-way analysis of variance was applied, and the unpaired Student's t-test was used to detect significant differences $(p<0.05)$ among treatments. Results are shown the mean \pm standard deviation (SD). Statistical significance is indicated as follows: a/ab $p<0.05$; a/b/c $p<0.01$. Data are representative of at least three independent experiments.

\section{RESULTS}

\section{Broiler distribution and climatic variation in the study areas}

We screened the secondary data of the government of Nepal and analyzed broiler distribution in the three climate zones (tropical, subtropical, and temperate). A significant difference was found in the chicken population in three climatic zones (Table 1). The tropical region of Nepal has a significantly higher poultry population than the subtropical and temperate regions.

We screened the previously reported data (MOAC, 2014) of three study areas, and detected significantly higher mean temperature, higher mean rainfall, and higher mean humidity in the tropical region compared with the other regions (Table 1).

\section{Growth performance parameters}

Daily feed intake was calculated after subtracting feed residues from feed offer. No significant feed intake differences were detected among the different between seasons. Broilers in the temperate zone presented significantly $(p=0.04)$ lower feed intake than those in the tropical and subtropical zones. However, comparing the interaction between seasons and climatic zones, the broilers reared during the winter in the temperate zone had significant lower feed intake $(p=0.031)$ (Table 4).

The water intake of the experimental birds was significantly different $(p=0.04)$ among climatic zones (Table 4), with broilers reared in the tropical and subtropical zones presenting higher water intake than those in the temperate zone. Moreover, water intake during the summer was significantly $(p=0.046)$ higher than in winter.

Final body weight was significantly $(p=0.01)$ affected by the seasons of the year, with final body weight determined in the winter than in the summer. Broilers reared in the tropical and subtropical zones were significantly $(p=0.021)$ higher body mass than bird's reared at temperate zone (Table 4).

There was significant effect of season $(p=0.004)$ on FCR, with better FCR obtained in winter than in the summer, and of climatic zone $(p=0.025)$, with the best FCR determined in the subtropical zone. There was a significant interaction between seasons and climatic zone for FCR values $(p<0.01)$ : the best FCR were obtained in broilers reared in the tropical and subtropical zones during winter (Table 4).

Total mortality was low: 4 birds in the summer experiment (temperate zone 1, subtropical zone 1, and tropical Zone $=2$ ) and 2 birds in the winter experiment

Table 4 - Broiler water intake (L), feed intake (g), total weight gain at 42 days of age (g) and FCR according to season and climatic zone.

\begin{tabular}{|c|c|c|c|c|c|}
\hline Factor & $\mathrm{N}$ & Water intake (L) & Feed intake (g) & $\begin{array}{c}\text { Total weight gain in } 42 \text { day }(\mathrm{g}) \\
\text { LS Mean } \pm \text { SE }\end{array}$ & FCR \\
\hline \multicolumn{6}{|l|}{ Seasons } \\
\hline Summer & 1530 & $12.1 \pm 0.47^{a}$ & $4018 \pm 0.43$ & $2016 \pm 0.43^{b}$ & $1.89 \pm 0.43^{b}$ \\
\hline Winter & 1530 & $11.3 \pm 0.13^{\mathrm{ab}}$ & $4121 \pm 0.43$ & $2173 \pm 0.43^{a}$ & $1.83 \pm 0.43^{a}$ \\
\hline \multicolumn{6}{|l|}{ Locations } \\
\hline Tropical & 1020 & $13.4 \pm 0.43^{a}$ & $4154 \pm 0.43^{a b}$ & $2204 \pm 0.43^{a}$ & $1.85 \pm 0.43^{\mathrm{ab}}$ \\
\hline Subtropical & 1020 & $12.1 \pm 0.43^{a}$ & $4165 \pm 0.43^{a b}$ & $2213 \pm 0.43^{a}$ & $1.82 \pm 0.43^{a b}$ \\
\hline Temperate & 1020 & $10.8 \pm 0.43^{\mathrm{ab}}$ & $3789 \pm 0.43^{a}$ & $1882 \pm 0.43^{\mathrm{ab}}$ & $1.94 \pm 0.43^{a}$ \\
\hline \multicolumn{6}{|l|}{ Interactions } \\
\hline Tropical × Summer & 510 & $14.1 \pm 0.88^{a}$ & $3843 \pm 0.62^{a b}$ & $2020 \pm 0.62^{\mathrm{ab}}$ & $1.87 \pm 0.62^{\mathrm{ab}}$ \\
\hline Tropical $\times$ Winter & 510 & $13.5 \pm 0.88^{a}$ & $4420 \pm 0.62^{a}$ & $2361 \pm 0.62^{a}$ & $1.81 \pm 0.62^{\mathrm{a}}$ \\
\hline Subtropical $\times$ Summer & 510 & $12.5 \pm 0.67^{a}$ & $4255 \pm 0.62^{a}$ & $2148 \pm 0.62^{a b}$ & $1.86 \pm 0.62^{\mathrm{ab}}$ \\
\hline Subtropical $\times$ Winter & 510 & $11.7 \pm 0.67^{a}$ & $4098 \pm 0.62^{a b}$ & $2298 \pm 0.62^{a}$ & $1.76 \pm 0.62^{a}$ \\
\hline Temperate $\times$ Summer & 510 & $10.7 \pm 0.46^{a b}$ & $3988 \pm 0.62^{a b}$ & $1918 \pm 0.62^{\mathrm{ab}}$ & $1.91 \pm 0.62^{b}$ \\
\hline Temperate $\times$ Winter & 510 & $9.38 \pm 0.46^{\mathrm{ab}}$ & $3692 \pm 0.62^{b}$ & $1842 \pm 0.62^{b}$ & $2.01 \pm 0.62^{c}$ \\
\hline
\end{tabular}

Results are shown as mean \pm standard error

a/ab significant at $95 \%$ level

a/b/c significant at 99\% level 
(temperate zone $=1$, tropical zone $=1$ ). Mortality was not affected by the treatments and therefore, the results are not shown.

\section{Blood corticosterone level and $\mathrm{H} / \mathrm{L}$ ratio}

Blood corticosterone (CORT) levels were not affected by season $(p=0.75)$. There was a significant effect of climatic zone on blood CORT levels $(p=0.006)$, with broilers from the tropical zone presenting the highest levels, followed by those in the temperate zone, and the lowest levels in the subtropical zone. The highest CORT levels $(3.61 \pm 0.93 \mathrm{ng} / \mathrm{mL})$ were detected in the tropical zone in the summer (Table 5), whereas the lowest $(3.17 \pm 0.31 \mathrm{ng} / \mathrm{mL})$ in the subtropical zone in the winter.

The $\mathrm{H} / \mathrm{L}$ ratio was highest in the birds of the tropical region during summer $(0.89 \pm 0.01)$ and lowest in subtropical birds at winter seasons $(0.71 \pm 0.02)$. Significant effect of the climate and weather on blood $\mathrm{H} / \mathrm{L}$ ratio was found between experimental birds $(p=0.003)$, (Table 5).

\section{DISCUSSION}

Monthly mean ranges of several climatic variables for different experiment period were taken into consideration for climatic variation as it can influence animal production (Gregory, 2010) including poultry. Since feed conversion ratio is the main factor that determines the profit/loss of the farm, and because feed accounts for more than $70 \%$ of the production costs (Osti et al., 2016), we calculated the average least mean square values for 6-week body weight, feed intake, water intake and FCR. Broiler feed intake was significantly different between the summer and the winter. A similar pattern was observed among the different climatic zones. The results revealed that the climate of the tropical zone was mostly humid during both the seasons and that the environmental temperature was higher than the comfort zone, whereas lower average temperatures were found in the temperate zone was found. Feed intake increases when broilers are maintained within the suitable

Table 5 - Blood corticosterone levels and heterophil to lymphocyte $(\mathrm{H} / \mathrm{L})$ ratiosof broilers according to season and climatic zone.

\begin{tabular}{llrl}
\hline Factor & $\mathrm{N}$ & Blood corticosterone level & Blood H/L ratio \\
\hline Seasons & & & $3.49 \pm 0.93$ \\
Summer & 153 & $3.61 \pm 0.93$ & $0.89 \pm 0.93$ \\
Winter & 153 & & $0.81 \pm 0.93$ \\
\hline Locations & & $3.52 \pm 0.13^{\mathrm{a}}$ & $0.85 \pm 0.13^{\mathrm{a}}$ \\
\hline Tropical & 102 & $3.28 \pm 0.43^{\mathrm{c}}$ & $0.74 \pm 0.43^{\mathrm{b}}$ \\
Subtropical & 102 & $3.37 \pm 0.19^{\mathrm{b}}$ & $0.77 \pm 0.73^{\mathrm{b}}$ \\
\hline Temperate & 102 & & $0.89 \pm 0.01^{\mathrm{b}}$ \\
\hline Interactions & & $3.61 \pm 0.93^{\mathrm{a}}$ & $0.81 \pm 0.62^{\mathrm{ab}}$ \\
\hline Tropical $\times$ Summer & 51 & $3.43 \pm 0.62^{\mathrm{ab}}$ & $0.76 \pm 0.62^{\mathrm{b}}$ \\
Tropical $\times$ Winter & 51 & $3.32 \pm 0.62^{\mathrm{ab}}$ & $0.71 \pm 0.01^{\mathrm{b}}$ \\
Subtropical $\times$ Summer & 51 & $3.17 \pm 0.31^{\mathrm{c}}$ & $0.79 \pm 0.62^{\mathrm{b}}$ \\
Subtropical $\times$ Winter & 51 & $3.33 \pm 0.62^{\mathrm{ab}}$ & $0.83 \pm 0.62^{\mathrm{ab}}$ \\
\hline Temperate $\times$ Summer & 51 & $3.45 \pm 0.62^{\mathrm{ab}}$ & \\
\hline Temperate $\times$ Winter & 51 & & \\
\hline
\end{tabular}

a ab significant at $95 \%$ level

a/blc significant at $99 \%$ level

comfort zone. Comfort zone of broilers was defined as that with temperature between 15 to $25^{\circ} \mathrm{C}$ and $60-65 \%$ humidity (El Boushy \& Van Marle, 1978), where the birds are able to regulate their heat balance relatively well and do not spend much energy on activity (Syafwan et al., 2011). The mean temperature and humidity of the subtropical zone was close to the comfort zone, and this may explain the higher feed intake of broilers reared in that zone. This finding is supported by a previous report (Al-Aqil et al., 2009), that state that optimal feed utilization and weight gain can be achieved by broilers when the environmental temperature is about $23^{\circ} \mathrm{C}$. In addition, long-term excessively high or low environmental temperatures have adverse effects on bird's physiology. In vertebrates, when females experience stress in the early stage of reproduction, their body hormonal balance can change, and the consequent effect is the epigenetic modification of the offspring. Exposure to stress activates the hypothalamic-pituitary-adrenal axis (HPA), with a subsequent increase of blood glucocorticoid levels. In avian species, the main glucocorticoid is corticosterone (CORT). Corticosterone acts mainly on the metabolism, and regulates energy intake, for 
instance (Sapolsky et al., 2000). At the peak of the hormonal effect, there is change in animal behavior. (Sapolsky et al., 2000; Tilgar et al., 2010).

Corticosterone is the main adrenocortical hormone present in the peripheral blood. Elevated blood corticosterone levels and heterophil to lymphocyte $(\mathrm{H} / \mathrm{L})$ ratios are well-known physiological indicators of welfare (Rogers et al., 2015; Alm et al., 2016), and are used as a stress indicators in poultry (Delezie et al., 2007; Cirule et al., 2012). Corticosteroids contribute for the reestablishment of homeostasis via negative feedback mechanisms that act on the hypothalamus and/or pituitary structures, decreasing HPA axis activation (Canoine et al., 2002). They promote adaptive behavioral responses by providing the metabolic requirements for flight or fight responses (Sapolsky et al., 2000). The significant increase in blood corticosteroid levels of the broilers reared in the tropical zone during the summer clearly indicate these birds were stressed due to climate and weather. This result was supported by the significantly higher $\mathrm{H} / \mathrm{L}$ ratios determined in those birds.

During severe heat stress, corticosterone is released, and consequently, its blood levels are increased in broilers (Zulkifli et al., 2009). Table 1 clearly indicates the extreme heat in the tropical zone may have induced heat stress in the broilers. It is well established that during heat stress, heat dissipation occurs by evaporative cooling, which, however, may be hindered if relative humidity is high. Therefore, in the tropical zone, the birds may have failed to cope with the hot and humid environment. Heat tolerance in birds helps to increase the level of heat shock protein (HSP) (Liew et al., 2003) as HSP modify protein folding and aids the body to handle with proteins affected by heat and other stressors (Gething \& Sambrook, 1992). During extremely hot weather, severe reduction in feed intake has been previously reported (Austic, 1985; Howlider \& Rose, 1987), which affects metabolism and results in low body growth (Morêki, 2008; Quinteiro-Filho et al., 2010). Particularly, protein digestion is hindered during chronic heat stress, leading to low feed intake (Larbier et al., 1993). When the temperature in above $32{ }^{\circ} \mathrm{C}$, feed intake is reduced by $5 \%$ for each degree of temperature increase (Balogun et al., 2013).

On the other hand, chickens are able to increase their body temperature when it falls below $20{ }^{\circ} \mathrm{C}$ (Dozier lii et al., 2003). However, when the environmental temperature is low, chickens need to use much of their energy to warm their body, therefore, deviating feed energy from growth. Oxygen requirements, cardiac output, and blood flow are higher during cold environmental temperatures, resulting in excessive pulmonary arterial pressure in the right ventricle and consequent development of ascites in broilers (Gleeson et al., 1986; Yahav et al., 1997). The heat gained or lost through radiation or conduction depends on the environmental temperature and its difference relative to body temperature. Birds try to dissipate heat during extreme heat and try to conserve heat during extreme cold temperature; however, in both cases birds need to expend a lot of energy to maintain their bodies within the comfort zone. This phenomenon is also correlated with water intake in poultry, as respiration rate severely increases in both during hot and cold stress (Morêki, 2008).

In conclusion, the tropical plains and the temperate mountains are relatively less favorable for broiler farming than the subtropical hills in the study area, as shown by their high blood corticosteroid levels and $\mathrm{H} / \mathrm{L}$ blood ratios and worse growth performance. We concluded the subtropical climatic zone causes relatively less stress in broilers as it is close to the comfort zone of broilers. Climatic stress plays a critical role on the physiology of broilers and impacts their final body weight. A combination of sound environmental and nutrition management will greatly improve production efficiency and yield maximum profitability.

\section{ACKNOWLEDGEMENT}

This research is financed by project "the Policy Impacts of Introducing Green Electricity Quota Trading System on the Sustainable Electricity Development in China" (Project No. 13YJA790163).The authors are thankful to Nepal Poultry Association, Nepal Egg Association, and Hatchery Association Nepal.

\section{CONFLICTS OF INTEREST}

The authors have no conflict of interest regarding the publication of this article.

\section{REFERENCES}

Alade O, Ademola A. Perceived effect of climate variation on poultry production in Oke Ogun area of Oyo State. Journal of Agriculture Science 2013;5:176.

Al-Aqil A, Zulkifli I, Sazili A, Omar A, Rajion M. The effects of the hot humid tropical climate and early age feed restriction on stress and fear responses, and performance in broiler chickens. Asian-Australian Journal of Animal Science 2009;22:1581-1586.

Alm M, Tauson R, Holm L, Wichman A, Kalliokoski O, Wall H. Welfare indicators in laying hens in relation to nest exclusion. Poultry Science $2016 ; 100$. 
Austic R. Feeding poultry in hot and cold climates. Washington: FAO; 1985.

Babinszky L, Halas V, Verstegen MW. Impacts of climate change on animal production and quality of animal food products. In: Blanco J, Kheradmand $\mathrm{H}$, editor. Climate change socioeconomic effects. Rijeka: InTech; 2011. p.165-190.

Balogun A, Akinseye F, Agbede J. Water and feed consumption in broiler birds during a typical hot weather condition in Akure, Ondo State, Nigeria. International Journal of Bio-Chemical Science 2013;7:11191125.

Barnett J, Hemsworth P. Science and its application in assessing the welfare of laying hens in the egg industry. Australian Veterinary Journal 2003;81:615-624.

Belda X, Fuentes S, Daviu N, Nadal R, Armario A. Stress-induced sensitization: the hypothalamic-pituitary-adrenal axis and beyond. Stress 2015;18:269-79.

Canoine V, Hayden TJ, Rowe K, Goymann W. The stress response of European stonechats depends on the type of stressor. Behavior 2002;139:1303-1311.

Chowdhury VS, Sultana H, Furuse M. International perspectives on impacts of reproductive technologies for world food production in Asia associated with poultry production. Advances in Experimental Medicine and Biology 2014;752:229-237.

Cirule D, Krama T, Vrublevska J, Rantala MJ, Krams I. A rapid effect of handling on counts of white blood cells in a wintering passerine bird: a more practical measure of stress? Journal of Ornithology 2012;153:161-166.

Delezie E, Swennen Q, Buyse J, Decuypere E. The effect of feed withdrawal and crating density in transit on metabolism and meat quality of broilers at slaughter weight. Poultry Science 2007;6:1414-1423.

Dozier lii W, Davis A, Freeman M, Ward T. Early growth and environmental implications of dietary zinc and copper concentrations and sources of broiler chicks. British Poultry Science 2003;44:726-731.

El Boushy AR, Van Marle AL. The effect of climate on poultry physiology in tropics and their improvement. World's Poultry Science Journal 1978;34:155-171.

Gething MJ, Sambrook J. Protein folding in the cell. Nature 1992;355:3345.

Gleeson M, Barnas G, Rautenberg W. The effects of hypoxia on the metabolic and cardiorespiratory responses to shivering produced by external and central cooling in the pigeon. Pflügers Archives 1986;407:312-319.

Gregory N. How climatic changes could affect meat quality. Food Research International 43:1866-1873

Harvey WR. Least square analysis of data with unequal subclass numbers. Washington: National Agricultural Library; 1990.

Howlider M, Rose S. Temperature and the growth of broilers. World's poultry Science Journal 2010;43:228-237.

Larbier M, Chagneau A, Geraert P. Influence of ambient temperature on true digestibility of protein and amino acids of rapeseed and soybean meals in broilers. Poultry Science 1993;72:289-295.

Liew P, Zulkifli I, Hair-Bejo M, Omar A, Israf D. Effects of early age feed restriction and heat conditioning on heat shock protein 70 expression, resistance to infectious bursal disease, and growth in male broiler chickens subjected to heat stress. Poultry Science 2003;82:1879-1885.

Mashaly MM. Hendricks GL, Kalama MA, Gehad AE, Abbas AO, Patterson $\mathrm{PH}$. Effect of heat stress on production parameters and immune responses of commercial laying hens. Poultry Science 2004;83: 889-94.
Mengesha M. Climate change and the preference of rearing poultry for the demands of protein foods. Asian Journal of Poultry Science 2004; $5: 135-143$

MOAC - Ministry of Agriculture and Cooperatives. Statistical information on Nepalese agriculture. Nepal; 2014.

Moreki J. Feeding strategies in poultry in hot climate. Poultry Today 2008;601:1-5

Okere I. Growth traits, breast meat yield and quality of broiler genotypes under hot conditions. Iranian Journal of Applied Animal Science 2014;4:159-164.

Osti R, Deyi Z, Virendra S, Dinesh B, Harshika C. An Economic Analysis of Poultry Egg Production in Nepal. Pakistan Journal of Nutrition 2016;15:715-724

Quinteiro-Filho WM, Ribeiro A, Ferraz-de-Paula V, Pinheiro ML, Sakai M, Sá $L R$, et al. Heat stress impairs performance parameters, induces intestinal injury, and decreases macrophage activity in broiler chickens. Poultry Science 2010;89(9):1905-14.

Ramachandran R. Current and future reproductive technologies for avian species. Advances in Experimental Medicine and Biology 2014;752:2331

Rogers AG, Pritchett EM, Alphin RL, Brannick EM, Benson ER. I. Evaluation of the impact of alternative light technology on male broiler chicken growth, feed conversion, and allometric characteristics. Poultry Science 2015:94:408-414

Sams A. The effect of seasonal heat stress on rigor development and the incidence of pale, exudative turkey meat. Poultry Science 1997;76:1616-1620.

Sapolsky RM, Romero LM, Munck AU. How do glucocorticoids influence stress responses? Integrating permissive, suppressive, stimulatory, and preparative actions 1. Endocrine Reviews 2000;21:55-89

Shini S, Kaiser P, Shini A, Bryden WL. Biological response of chickens (Gallus gallus domesticus) induced by corticosterone and a bacterial endotoxin. Comparative Biochemistry and Physiology Part B: Biochemistry Molecular and Biology 2008;149:324-333.

Syafwan S, Kwakkel RP, Verstegen MW. Heat stress and feeding strategies in meat-type chickens. World's Poultry Science Journal 2011;67:653674.

Tilgar V, Saag P, Külavee R, Mänd R. Behavioral and physiological responses of nestling pied flycatchers to acoustic stress. Hormone Behaviour 2010;57:481-487

UNO - United Nations Organisation. Department of Economic and Social Affairs website; 2015. Available from: http://www.un.org/en/ development/desa/news/population/2015-report.html

Vantress C. 2011. Available from: http://cobb-vantress.com/docs/defaultsource/guides/cobb-broiler-management-guide---english.pdf

Windhorst HW. Global egg production dynamics-past, present and future of a remarkable success story. Wing; 2011

Yahav S, Straschnow A, Plavnik I, Hurwitz S. Blood system response of chickens to changes in environmental temperature. Poultry Science 1997;76:627-633.

Zulkifli I, Al-Aqil A, Omar AR, Sazili AQ, Rajion MA. Crating and heat stress influence blood parameters and heat shock protein 70 expression in broiler chickens showing short or long tonic immobility reactions. Poultry Science 2009;88:471-476. 
